The Israel-Egypt peace treaty has opened up the possibility of scientific links. Here, 'Nature' correspondents describe the views from Cairo and Tel Aviv Egypt: divided and uncertain

THE Egyptian scientific community is divided on the issue of collaboration with Israel. A small number of high ranking scientists see many advantages in undertaking joint projects; they argue that the Israelis have certain expertise in research areas that are important to Egypt, and Egypt should take advantage of the Israeli offer to collaborate in these areas.

There is, however, considerable opposition to this view from the rank-andfile scientists. Their argument is that the essential need of Egypt is not expertise but funding. If Israel can fund Egyptian research ventures, all well and good; but that's where collaboration ends. The Americans and Europeans already occupy positions of prestige in Egyptian scientific establishments as advisers and consultants, and many Egyptian scientists fear that Israelis will be added to the list. And they consider this not so much collaboration but more a form of domination.

Over the last few years, the Egyptian scientific community has been looking more and more towards the Arab OPEC countries as a major source of funding. A number of Egyptian projects in solar energy, desalination, oceanography, pollution studies and agriculture are already being financed by some of these countries, while Egyptian scientists and technicians form the backbone of industry and academia in Saudi Arabia, Kuwait, Bahrain and the United Arab Emirates. Despite the Arab boycott of Egypt, these scientists continue to work in Arab OPEC countries, many joint projects still continue, and these countries continue to recruit scientists and technicians from Egypt. The expectation of further collaboration with Arab OPEC countries is, therefore, much stronger than the possibility of co-operation with Israel. Many Egyptian scientists believe that cooperation with Israel will seriously damage the possibility of further collaboration with the Arab OPEC countries.

Dr Fahamy Ramadan, Secretary General of the National Research Centre of Cairo, sums up the feeling of many Egyptian scientists when he says: "All Arabs are brothers. Brothers fight; but they do not stay divided for long. They eventually make up. Our Arab brothers will make up with us, and much sooner than most people think'. It seems that most Egyptian scientists would rather wait for their "Arab brothers" to make up with them then actively collaborate with Israel.

Ziauddin Sardar

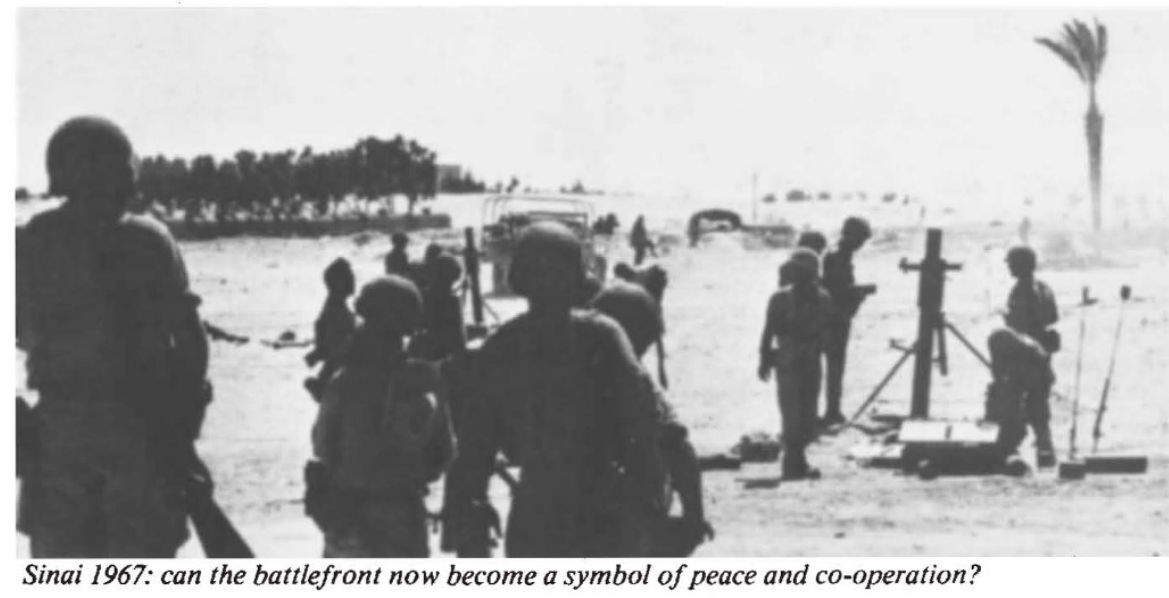

\title{
Israel: a one-sided love affair
}

Discussions about scientific and technological co-operation between Israel and Egypt have so far been very much like a one-sided love affair; while dozens of Israeli professors and politicians have spoken about the potential benefits of such co-operation little response has been forthcoming from their counterparts in Egypt. To be sure, there have been unofficial meetings between top Egyptian and Israeli scientists in third countries like the US and Germany usually on the initiative of well-meaning intermediaries. But so far the Egyptians have avoided public statements on the subject.

Yet the Israelis go on hoping and talking. The most dramatic presentation of a cooperation scheme was made some two months ago during Sadat's visit to Beersheba by Joseph Tekoah, former Israel ambassador to the UN and new president of Ben-Gurion University of the Negev. Speaking at an internationally televised campus ceremony, with Begin and Sadat on either side, Tekoah announced that the university had decided to establish a $\$ 100 \mathrm{~m}$ fund for desert research of potential benefit to both Israel and Egypt. Egyptian scientists, he added, were invited to participate in the research projects and in the fund's administration. Sadat was all smiles, but that - so far has been the only Egyptian response.

Slightly more guarded was the recent statement by Haifa Technion president Amos Horev, who expressed the Technion's willingness to enter into bilaterial relations with Egyptian institutions. As a first step he expected that Egyptian technological and science university graduates might study for higher degrees at the Technion, and that Egypt might wish to utilize the Technion's research laboratories and testing facilities. But under no circumstances, Horev warned, should Israelis delude themselves into thinking that they were goiong to 'save Egypt'.

The most logical place for co-operation to begin would be the Sinai peninsula, where for the last 12 years Israeli scientists have done extensive research, the results of which are now being turned over to the returning Egyptians. This is by no means a new idea, as a number of American Presidents, beginning with Eisenhower, have suggested the establishment in Sinai of joint Israeli-Egyptian power stations and desalination plants. Before this scheme was finally shelved, scientists working at the Oak Ridge National Laboratory under Dr Alvin Weinberg had produced a detailed report on how it could be carried out. They envisaged the installation of two reactors with a combined output of 1000 MW, which would provide power for new industries producing chemicals, fertilizers, plastics and aluminium, as well as for desalinating enough water to irrigate 300,000 acres of land in Egypt and the Negev desert.

These plans still exist, as do new ones engendered by the euphoria of peace. Yet the Egyptians remain reticent, as is evident in the experiences of an Israeli scientist who has just returned from a visit to Egypt. He travelled there on a second, non-Israeli passport, but his hosts, top figures in the Egyptian scientific establishment, know that he lives in Israel, as does anyone who reads his papers in the journals. Behind closed doors the Egyptian scientists spoke enthusiastically about the possibility of cooperation with Israel in spheres like agriculture, medicine, solar energy and desalination. Yet when someone came into the room, such discussions stopped and the guest was introduced as being from Europe.

In order to overcome this apparent Egyptian hesitance about bi-national cooperation, leading Israeli scientists have suggested that international organizations should sponsor large scientific conferences in Israel and in Egypt, where it is hoped there would be massive participation of Israeli scientists when the meeting took place in Egypt, and of Egyptian scientists when it was in Israel. Moreover, people here place great stress on the need to choose topics where the Egyptians excel and can teach the Israelis, as well as fields where the opposite situation exists.

Nechemia Meyers 